\title{
Bioefficacy of Emamectin Benzoate Against Helicoverpa armigera Hubner and its Natural Enemies on chickpea (Cicer arietinum) Crop
}

\author{
Kailash Chaukikar*, A. K. Bhowmick, S. B. Das, R. S. Marabi and Vivek Singh Tomar \\ Dept. of Entomology, College of Agriculture, JNKVV, Jabalpur, M.P. (482 004), India
}

\section{Corresponding Author}

Kailash Chaukikar

e-mail: kailashento@gmail.com

\author{
Article History \\ Article ID: AR1818e \\ Received in $14^{\text {th }}$ June, 2017 \\ Received in revised form $15^{\text {th }}$ September, 2017 \\ Accepted in final form $29^{\text {th }}$ September, 2017
}

\begin{abstract}
An experiment was carried out to investigate the bioefficacy of Emamectin benzoate against the larvae of Helicoverpa armigera and its natural enemies on chickpea at Breeding Seed Production Farm, JNKVV, Jabalpur, Madhya Pradesh, India, consecutively for two years during rabi season 2009 and 2010. The trial was laid out in Randomized Block Design with seven treatments and three replications. The pooled data of two years indicated that Emamectin benzoate 5\% WG @ 9.4 and $8.1 \mathrm{~g}$ a.i. ha ${ }^{-1}$ were found to be most effective dose in reducing the $H$. armigera larval population and pod damage (1.28\% and 1.29\%, respectively) followed by Emamectin benzoate 5\% WG @ 6.9 and $5.6 \mathrm{~g}$ a.i. ha ${ }^{-1}$ with 1.33 and $3.72 \%$ pod damage, respectively. The standard treatments of Chlorpyrifos $20 \%$ EC @ $500 \mathrm{~g}$ a.i. ha- ${ }^{-1}$ and Ethion $50 \%$ EC @ 500 g a.i. ha ${ }^{-1}$ recorded $7.40 \%$ and $7.72 \%$ pod damage, respectively as compared to control plot (10.89\% pod damage). All the treatments of Emamectin benzoate 5\% WG did not show any adverse effects against Lady bird beetle and Chrysopa and no phytotoxic effects was observed on the chickpea crop. Seed yield was maximum ( $\left.2260 \mathrm{~kg} \mathrm{ha}^{-1}\right)$ with the highest dose of Emamectin benzoate $5 \%$ WG @ 9.4 g a.i ha- ${ }^{-1}$ followed by Emamectin benzoate 5\% WG @ 8.1 and $6.9 \mathrm{~g}$ a.i ha ${ }^{-1}$, respectively.
\end{abstract}

Keywords: Chickpea, Helicoverpa amigera, natural enemies, emamectin benzoate, yield

\section{Introduction}

Chickpea (Cicer arietinum L.) is one of the most important pulse crop which is cultivated worldwide. It is consumed as vegetable, pulse, flour, variety of snacks, sweets and other different culinary dishes. Among the pulses crop chickpea is a highly nutritious having best source of proteins (12$31 \%)$, carbohydrates (60-65\%), fat (6\%) and different kind of vitamins (Saharan and Khetarpaul, 1994; Kumar et al., 2015). India is the world's largest producer and consumer of chickpea which occupies first position in the world in area and production. In India the crop is grown about 8.25 mha area with the production of $7.33 \mathrm{mt}$ and productivity of $889 \mathrm{~kg} \mathrm{ha}^{-1}$. Whereas, in Madhya Pradesh chickpea is cultivated in about $2.85 \mathrm{mha}$ with production of $2.96 \mathrm{mt}$ with the productivity of $1039 \mathrm{~kg} \mathrm{ha}^{-1}$ (Agricultural Statistics at a Glance, 2016). But, last few decades it has been reported that the area, production and productivity of chickpea is declining. To boost up the production of chickpea, one of the most practical resorts of increasing chickpea production is to minimize losses caused by the biotic constraints, which include insect-pests, diseases and weeds under field conditions. Among the prevalent biotic factors about 36 different species of insect pests has been reported to attack chickpea during different growth stages of the crop in India (Nayer et al., 1982). Of them gram pod borer (Helicoverpa armigera Hubner) is the only major and most devastating pest which alone causes $29 \%$ yield losses in chickpea at national level. It is a cosmopolitan and polyphagous pest, feeds on more than 300 plant species and responsible for considerable economic damage to many field and horticultural crops (Sachan, 1992; Arora et al., 2005). The incidence of this insect begins from early vegetative to maturity stage of the crop. At early stage, the young larvae starts feeding on leaflets, buds, flowers and finally green pods of chickpea. Owing to this, reduction in yield ranged from $40-50 \%$ has been recorded and may cause even total loss of the crop (Rai et al., 2003; Mandal and Roy, 2012). The annual losses due to insect pests have been estimated up to $15 \%$ in chickpea (Chandrashekar et al., 2014). Crop damage by insect pests could be minimized and kept under economic threshold level effectively by considering one of the important component of integrated pest management i.e., chemical control by selecting some newer insecticides which should be selective, safer and less harmful to natural enemies. Comprehensive scientific data in respect of toxicity, effectiveness and economics of the chemical insecticide is incredibly essential in decision making towards the pest management. Thus, keeping the above views in mind, the present study was carried out to investigate the 
efficacy of some most popular chemical insecticides against the gram pod borer in chickpea ecosystem.

\section{Materials and Methods}

A field experiment was conducted during two consecutive rabi season 2009 and 2010 at Breeding Seed Production Farm, Jawaharlal Nehru Krishi Vishwa Vidyalaya, Jabalpur, Madhya Pradesh, India to investigate the bio-efficacy of Emamectin benzoate 5\% WG against pod borer and its natural enemies on chickpea. The variety of test crop was JG-1-09. The trial was laid out in Randomized Block Design with seven treatments and three replications. Plot size was $4 \times 5 \mathrm{~m}^{2}$ with row $\times$ plant spacing of $45 \times 05 \mathrm{~cm}^{2}$. Three foliar sprays of the insecticides were applied initiating at 50\% flowering and repeated at 15 days interval with a high volume Knapsack sprayer @ 500 liter spray fluid ha-1. Due care was taken to avoid the drift of insecticides on neighboring plots. The observations on larval population were recorded one day before spray and 3,7 and 10 days after each spray from one meter row length $\left(\mathrm{mrl}^{-1}\right)$ of chickpea crop, at three different sites plot ${ }^{-1}$. Similar method was also followed to count the occurrence of natural enemies. Mean larval populations were transformed to square root transformation for statistical analysis. Pod damage were recorded on ten randomly selected plants plot $^{-1}$ at the time of harvest by counting the total number of healthy and damaged pods and percent pod damage was computed as suggested by Kumar et al. (2013).

Percent pod damage $(\%)=\frac{\text { Total no. of damaged pods }}{\text { Total no. of examined pods }}$

The percent pod damage was transformed to angular transformation values for statistical analysis. Similarly grain yield was recorded from each plot after harvest and converted to yield ha-1. Observations on phytotoxicity symptoms were recorded visually as per the guidelines of Central Insecticide Board, Govt. of India on 0-10 scale, EWRC system (Table 1). Effect on crop health viz., leaf yellowing, tip necrosis, scorching, epinasty and hyponasty etc., were recorded on 1, $3,5,7$ and 10 days after application of each spray using the following score and per cent effect was worked out as per the method proposed by Nishantha et al. (2009).

Table 1: Scale for rating phytotoxicity symptoms caused be insecticides on chickpea

\begin{tabular}{lccc}
\hline $\begin{array}{c}\text { Score } \\
(\%)\end{array}$ & $\begin{array}{c}\text { Crop health affected } \\
\text { (\%) phytotoxicity }\end{array}$ & Score & $\begin{array}{c}\text { Crop health } \\
\text { affected } \%\end{array}$ \\
\hline 0 & $1-10$ & 7 & $51-60$ \\
1 & $11-20$ & 8 & $61-70$ \\
2 & $21-30$ & 9 & $71-80$ \\
3 & $31-40$ & 10 & $81-90$ \\
4 & $41-50$ & & $91-100$ \\
5 & & & \\
\hline
\end{tabular}

\section{Results and Discussion}

\subsection{Management of Helicoverpa armigera}

The perusal of pooled data of two years revealed that the larval population of gram pod borer ranged between 4.97 and 5.17 larvae $\mathrm{mrl}^{-1}$ before first spray of insecticides, which was statistically identical in different plots. At 3 DA1A (Days after first application) all the insecticidal treatments were significantly superior as compared to control in reducing the larval population and it ranged from 1.86 to 4.65 larvae $\mathrm{mrl}^{-1}$ in different treatments as against 5.42 larvae $\mathrm{mrl}^{-1}$ in control plot (Table 2). All the treatments were found very effective and significantly at par with each other except control. However, treatments viz; $T_{5}, T_{4}, T_{3}$ and $T_{2}$ (Emamectin benzoate 5\% WG @ $9.4,8.1,6.9$ and $5.6 \mathrm{~g}$ a.i. $\mathrm{ha}^{-1}$ ) were significantly superior and at par with each other and recorded 1.86, 1.94, 2.10 and 3.74 larvae $\mathrm{mrl}^{-1}$ respectively. At 7 and 10 DA1A all the insecticidal treatments were significantly superior to control plot in declining the the larval population. However, Emamectin benzoate 5\% WG @ $9.4 \mathrm{~g}$ a.i. ha ${ }^{-1}$ was significantly superior and at par with each other. Similar trends were observed after $2^{\text {nd }}$ and $3^{\text {rd }}$ spray application. At 3, 7 and 10 DA2A (Days after second application) the larval population of gram pod borer in control plot was in the range of 6.67 to 6.93 larvae $\mathrm{mrl}^{-1}$. Further at 3, 7 and 10 DA2A the larval population was significantly declined in all the treatments except control plot. Treatments $T_{5}$ (Emamectin benzoate 5\% WG @ $9.4 \mathrm{~g}$ a.i. ha $^{-1}$ ) reduced the larval population at 3, 7 and 10 DA2A which recorded $0.57,0.19$ and 0.08 larvae $\mathrm{mrl}^{-1}$ followed by $\mathrm{T}_{4}\left(0.68,0.28\right.$ and 0.09 larvae $\left.\mathrm{mrl}^{-1}\right)$ and $\mathrm{T}_{3}(0.05,0.39$ and 0.10 larvae $\mathrm{mrl}^{-1}$ ), respectively, whereas rest of the other treatments were at par with each other. At 3, 7 and 10 DA3A treatment $T_{5}$ recorded least larval population $(0.01,0.00$ and 0.00 larvae $\left.\mathrm{mrl}^{-1}\right)$ followed by $\mathrm{T}_{4}(0.11,0.00$ and 0.00 larvae $\left.\mathrm{mrl}^{-1}\right), \mathrm{T}_{3}\left(0.14,0.06\right.$ and 0.00 larvae $\mathrm{mrl}^{-1}$ ) and $\mathrm{T}_{2}$ (1.34 0.62 and 0.34 larvae $\mathrm{mrl}^{-1}$ ), respectively, while rest of the other treatments less effective and were at par with each other but superior to control plot.

Pooled data of two years data at harvest indicated that both doses of Emamectin benzoate 5\%WG @ 9.4 and $8.1 \mathrm{~g}$ a.i. $\mathrm{ha}^{-1}$ were found to be most effective which recorded $1.28 \%$ and $1.29 \%$ pod damage followed by Emamectin benzoate $5 \%$ WG @ 6.9 and $5.6 \mathrm{~g}$ a.i. ha ${ }^{-1}$ (1.33 and 3.72\% pod damage, respectively). The standard checks Chlorpyrifos 20\% EC @ $500 \mathrm{~g}$ a.i. ha ${ }^{-1}$ and Ethion 50\% EC @ 500 g a.i. ha ${ }^{-1}$ recorded $7.40 \%$ and $7.72 \%$ pod damage, respectively as compared to control plot which was maximum $10.89 \%$ pod damage (Table 3). Emamectin benzoate $5 \mathrm{~g}$ a.i. ha $^{-1}$ recorded minimum gram pod borer larval population $(0.33,5.00,7.00,4.00$ and 2.33 plot $^{-1}$ on $5^{\text {th }}, 10^{\text {th }}, 15^{\text {th }}, 20^{\text {th }}$ days after spray and at harvest, respectively). Moreover, after sound spray significantly lowest pod damage was recorded Emamectin benzoate ( $5 \mathrm{~g}$ a.i. ha ${ }^{-1}$ ) on $5^{\text {th }}(1.49 \%), 10^{\text {th }}(2.9 \%), 15^{\text {th }}(3.52 \%), 20^{\text {th }}(4.49 \%)$ day after sprays and at harvest $(5.00 \%)$, respectively, in comparison to 


\begin{tabular}{|c|c|c|c|c|c|c|c|c|c|c|c|c|}
\hline \multirow{3}{*}{$\begin{array}{l}\text { SI. } \\
\text { No. }\end{array}$} & \multicolumn{2}{|c|}{ Dose } & \multicolumn{10}{|c|}{ No. of larvae $/ \mathrm{mrl}^{*}$} \\
\hline & \multirow{2}{*}{$\begin{array}{l}\text { g a.i } \\
\text { ha-1 }^{-1}\end{array}$} & \multirow{2}{*}{$\begin{array}{c}\text { Product } \\
(\mathrm{g}, \mathrm{ml} \\
\left.\mathrm{ha}^{-1}\right)\end{array}$} & \multicolumn{4}{|c|}{ (1 $1^{\text {st }}$ spray) } & \multicolumn{3}{|c|}{ ( $2^{\text {nd }}$ spray) } & \multicolumn{3}{|c|}{ (3 $3^{\text {rd }}$ spray) } \\
\hline & & & $\begin{array}{l}\text { Pre } \\
\text { count }\end{array}$ & $\begin{array}{c}3 \\
\text { DA1A }\end{array}$ & $\begin{array}{c}7 \\
\text { DA1A }\end{array}$ & $\begin{array}{c}10 \\
\text { DA1A }\end{array}$ & $\begin{array}{c}3 \\
\mathrm{DA} 2 \mathrm{~A}\end{array}$ & $\begin{array}{c}7 \\
\text { DA2A }\end{array}$ & $\begin{array}{c}10 \\
\text { DA2A }\end{array}$ & $\begin{array}{c}3 \\
\text { DA3A }\end{array}$ & $\begin{array}{c}7 \\
\text { DA3A }\end{array}$ & $\begin{array}{c}10 \\
\text { DA3A }\end{array}$ \\
\hline $\mathrm{T}_{1}$ & - & - & $\begin{array}{c}5.09 \\
(2.35)\end{array}$ & $\begin{array}{c}5.42 \\
(2.42)\end{array}$ & $\begin{array}{c}5.74 \\
(2.49)\end{array}$ & $\begin{array}{c}6.27 \\
(2.60)\end{array}$ & $\begin{array}{c}6.67 \\
(2.69)\end{array}$ & $\begin{array}{c}6.68 \\
(2.71)\end{array}$ & $\begin{array}{c}6.93 \\
(2.72)\end{array}$ & $\begin{array}{c}4.10 \\
(2.14)\end{array}$ & $\begin{array}{c}3.66 \\
(2.04)\end{array}$ & $\begin{array}{c}3.42 \\
(1.97)\end{array}$ \\
\hline $\mathrm{T}_{2}$ & 5.6 & $112 \mathrm{~g}$ & $\begin{array}{c}5.08 \\
(2.35)\end{array}$ & $\begin{array}{c}3.74 \\
(2.04)\end{array}$ & $\begin{array}{c}2.90 \\
(1.84)\end{array}$ & $\begin{array}{c}2.38 \\
(1.69)\end{array}$ & $\begin{array}{c}2.02 \\
(1.58)\end{array}$ & $\begin{array}{c}1.91 \\
(1.55)\end{array}$ & $\begin{array}{c}0.48 \\
(0.99)\end{array}$ & $\begin{array}{c}1.34 \\
(1.35)\end{array}$ & $\begin{array}{c}0.62 \\
(1.05)\end{array}$ & $\begin{array}{c}0.34 \\
(0.91)\end{array}$ \\
\hline $\mathrm{T}_{3}$ & 6.9 & $138 \mathrm{~g}$ & $\begin{array}{c}4.97 \\
(2.32)\end{array}$ & $\begin{array}{c}2.10 \\
(1.58)\end{array}$ & $\begin{array}{c}1.76 \\
(1.49)\end{array}$ & $\begin{array}{c}1.17 \\
(1.27)\end{array}$ & $\begin{array}{c}0.75 \\
(1.09)\end{array}$ & $\begin{array}{c}0.39 \\
(0.94)\end{array}$ & $\begin{array}{c}0.10 \\
(0.77)\end{array}$ & $\begin{array}{c}0.14 \\
(0.80)\end{array}$ & $\begin{array}{c}0.06 \\
(0.75)\end{array}$ & $\begin{array}{c}0.00 \\
(0.71)\end{array}$ \\
\hline $\mathrm{T}_{4}$ & 8.1 & $162 \mathrm{~g}$ & $\begin{array}{c}5.03 \\
(2.34)\end{array}$ & $\begin{array}{c}1.95 \\
(1.52)\end{array}$ & $\begin{array}{c}1.72 \\
(1.47)\end{array}$ & $\begin{array}{c}1.14 \\
(1.26)\end{array}$ & $\begin{array}{c}0.68 \\
(1.06)\end{array}$ & $\begin{array}{c}0.28 \\
(0.88)\end{array}$ & $\begin{array}{c}0.09 \\
(0.77)\end{array}$ & $\begin{array}{c}0.11 \\
(0.78)\end{array}$ & $\begin{array}{c}0.00 \\
(0.71)\end{array}$ & $\begin{array}{r}0.00 \\
(0.71)\end{array}$ \\
\hline $\mathrm{T}_{5}$ & 9.4 & $188 \mathrm{~g}$ & $\begin{array}{c}5.17 \\
(2.37)\end{array}$ & $\begin{array}{c}1.86 \\
(1.50)\end{array}$ & $\begin{array}{c}1.39 \\
(1.35)\end{array}$ & $\begin{array}{c}0.91 \\
(1.16)\end{array}$ & $\begin{array}{c}0.57 \\
(1.01)\end{array}$ & $\begin{array}{c}0.19 \\
(0.83)\end{array}$ & $\begin{array}{c}0.08 \\
(0.76)\end{array}$ & $\begin{array}{c}0.01 \\
(0.71)\end{array}$ & $\begin{array}{c}0.00 \\
(0.71)\end{array}$ & $\begin{array}{c}0.00 \\
(0.71)\end{array}$ \\
\hline$T_{6}$ & 500 & $\begin{array}{c}2500 \\
\mathrm{ml}\end{array}$ & $\begin{array}{c}5.04 \\
(2.34)\end{array}$ & $\begin{array}{c}4.51 \\
(2.23)\end{array}$ & $\begin{array}{c}3.65 \\
(2.03)\end{array}$ & $\begin{array}{c}3.55 \\
(2.01)\end{array}$ & $\begin{array}{c}3.98 \\
(2.12)\end{array}$ & $\begin{array}{c}3.95 \\
(2.11)\end{array}$ & $\begin{array}{c}3.83 \\
(2.08)\end{array}$ & $\begin{array}{c}2.68 \\
(1.78)\end{array}$ & $\begin{array}{c}2.81 \\
(1.82)\end{array}$ & $\begin{array}{c}2.67 \\
(1.77)\end{array}$ \\
\hline $\mathrm{T}_{7}$ & 500 & $\begin{array}{c}1000 \\
\mathrm{ml}\end{array}$ & $\begin{array}{c}5.12 \\
(2.36)\end{array}$ & $\begin{array}{c}4.65 \\
(2.26)\end{array}$ & $\begin{array}{c}4.04 \\
(2.12)\end{array}$ & $\begin{array}{c}3.90 \\
(2.10)\end{array}$ & $\begin{array}{c}4.25 \\
(2.17)\end{array}$ & $\begin{array}{c}4.06 \\
(2.13)\end{array}$ & $\begin{array}{c}3.98 \\
(2.12)\end{array}$ & $\begin{array}{c}2.80 \\
(1.81)\end{array}$ & $\begin{array}{c}2.69 \\
(1.78)\end{array}$ & $\begin{array}{c}2.54 \\
(1.74)\end{array}$ \\
\hline SEm & & & 0.02 & 0.05 & 0.04 & 0.05 & 0.06 & 0.04 & 0.03 & 0.06 & 0.05 & 0.07 \\
\hline CD & $\mathrm{p}=0.05)$ & & NS & 0.16 & 0.11 & 0.02 & 0.18 & 0.12 & 0.10 & 0.18 & 0.15 & 0.22 \\
\hline
\end{tabular}

$\mathrm{T}_{1}$ : Control; $\mathrm{T}_{2}$ : Emamectin benzoate 5\% WG; $\mathrm{T}_{3}$ : Emamectin benzoate $5 \% \mathrm{WG} ; \mathrm{T}_{4}$ : Emamectin benzoate $5 \% \mathrm{WG} ; \mathrm{T}_{5}$ : Emamectin benzoate $5 \%$ WG; $\mathrm{T}_{6}$ : Chloropyrifos $20 \% \mathrm{EC} ; \mathrm{T}_{7}$ : Ethion $50 \% \mathrm{EC}$; Figures in parenthesis are square root transformed values $(\mathrm{VX}+0.5) ; \mathrm{mrl}^{*}:$ meter row length; DA1A: days after $1^{\text {st }}$ application; DA2A: Days after $2^{\text {nd }}$ application, DA3A: days after $3^{\text {rd }}$ application

untreated control (Bharti et al., 2015). Mittal and Ujagir (2005) also recorded lower number of gram pod borer larvae and lower pod damage with different concentrations of Spinosad in pigeonpea. This was followed by Flubendiamide (2.46\%), Chlorantraniliprole $(2.60 \%)$, Emamectin benzoate $(2.85 \%)$ but were at par with Indoxacarb (3.18\%) and recorded 81.9, $80.9,79.1$ and $76.7 \%$ reduction in pod damage over control, respectively. Raghuraman et al. (2008) also reported that Emamectin benzoate (11 g a.i. ha ${ }^{-1}$ ) to be highly effective in reducing the incidence of bollworm in cotton and increased the yield. Kumar and Sarada (2015) observed that pod damage due to gram pod borer larvae was lowest in plots treated with Spinosad 45 SC (1.53\%), Flubendiamide 20 WG (2.46\%), Chlorantraniliprole $20 \mathrm{SC}$ (2.60\%) and Emamectin benzoate 5 SG (2.85\%) with $88.8,81.9,80.9$ and $79.1 \%$ reduction over control, respectively. Sarnaik and Chiranjeevi (2017) also corroborates with the present findings and reported Emamectin benzoate 5 WG @ $15.0 \mathrm{~g}$ a.i. ha ${ }^{-1}$ to be the best treatment with minimum $H$.armigera larval population $(0.37$, 0.27 and 0.13 larvae plant ${ }^{-1}$ ) and lowest pod damage (8.30, 6.89 and $5.83 \%$ pod damage) at one, three and seven days after spray, respectively.

\subsection{Effect on natural enemies of gram pod borer}

The population of Lady bird beetle and Chrysopa were negligible during the study period and the at different doses of Emamectin benzoate 5\% WG statistical analysis was significant (Table 4). However, the population of beneficial insects at different doses of Emamectin benzoate 5\% WG were near about the same as the control plots. In the present study Emamectin benzoate was found to be much safer to the beneficial insects as compared to Chlorpyrifos and Ethion. The present findings are in agreement with those of Kambrekar et al. (2012) they also recorded that Emamectin benzoate 5\% SG @ $13 \mathrm{~g}$ a.i. ha ${ }^{-1}$ was safer and had no adverse effects showed on the natural enemies and no phytotoxic effects on chickpea crop.

\subsection{Seed yield}

All the doses of Emamectin benzoate 5\% WG recorded significantly higher seed yield over control plot (Table 3). Maximum seed yield $2260 \mathrm{~kg} \mathrm{ha}^{-1}$ was obtained with Emamectin benzoate 5\% WG @ 9.4 followed by $T_{4}$ and $T_{3}$ (2188 and $2149 \mathrm{~kg} \mathrm{ha}^{-1}$, respectively) while lower dose of this insecticide recorded lower seed yield $\left(1810 \mathrm{~kg} \mathrm{ha}^{-1}\right)$. Whereas, recommended standard insecticides like Chlorpyrifos $20 \%$ EC @ 500 g a.i. ha ${ }^{-1}$ and Ethion 50\% EC @ 500 g a.i. ha ${ }^{-1}$ recorded lower seed yield (1862 and $1807 \mathrm{~kg} \mathrm{ha}^{-1}$ ) as compared to all the doses of Emamectin benzoate 5\% WG. Kumar and Sarada 


\begin{tabular}{|c|c|c|c|c|}
\hline \multirow[t]{2}{*}{ SI. No. } & \multicolumn{2}{|c|}{ Dose } & \multirow{2}{*}{$\begin{array}{l}\text { \% Pod damage } \\
\text { (At harvest)* }\end{array}$} & \multirow{2}{*}{$\begin{array}{l}\text { Yield } \\
\left(\mathrm{kg} \mathrm{ha}^{-1}\right)\end{array}$} \\
\hline & $\begin{array}{l}\text { g a.i } \\
\text { ha }^{-1}\end{array}$ & $\begin{array}{l}\text { Product } \\
\left(\mathrm{g}, \mathrm{ml} \mathrm{ha}^{-1}\right)\end{array}$ & & \\
\hline $\mathrm{T}_{1}$ & - & - & $10.89(19.26)$ & 1709 \\
\hline $\mathrm{T}_{2}$ & 5.6 & $112 \mathrm{~g}$ & $3.72(11.07)$ & 1810 \\
\hline $\mathrm{T}_{3}$ & 6.9 & $138 \mathrm{~g}$ & $1.33(6.62)$ & 2149 \\
\hline $\mathrm{T}_{4}$ & 8.1 & $162 \mathrm{~g}$ & $1.29(6.65)$ & 2188 \\
\hline $\mathrm{T}_{5}$ & 9.4 & $188 \mathrm{~g}$ & $1.28(6.51)$ & 2260 \\
\hline $\mathrm{T}_{6}$ & 500 & $2500 \mathrm{ml}$ & 7.40 (15.78) & 1862 \\
\hline $\mathrm{T}_{7}$ & 500 & $1000 \mathrm{ml}$ & $7.72(16.12)$ & 1807 \\
\hline \multicolumn{3}{|l|}{ SEm \pm} & 0.37 & - \\
\hline \multicolumn{3}{|c|}{$\mathrm{CD}(p=0.05)$} & 1.13 & - \\
\hline
\end{tabular}

*Figures in parenthesis are angular transformed values

(2015) recoded highest yield in Spinosad 45\% SC treated plots (1244.4 $\mathrm{kg} \mathrm{ha}^{-1}$ ) with $121.8 \%$ increase over control, followed by Chlorantraniliprole $20 \%$ SC (1180.5 kg ha-1), Flubendiamide 20\% WG (1157.4 kg ha-1) and Emamectin benzoate 5\% SG $\left(1078.7 \mathrm{~kg} \mathrm{ha}^{-1}\right.$ ) with $110.4,106.3$ and $92.2 \%$ increase over control, respectively. Sharma et al. (2011) reported Emamectin benzoate to be most effective in minimizing yield losses caused by $H$. armigera in pigeonpea, which supports the present findings. Raghuraman et al. (2008) also agreed and found to Emamectin benzoate (11 g a.i. ha ${ }^{-1}$ ) as most effective in reducing the incidence of bollworm in cotton and increased the yield. Bharti et al. (2015) found Emamectin benzoate 5 WSG at @ $5 \mathrm{~g}$ a.i. ha ${ }^{-1}$ to be effective against gram pod borer which recorded maximum seed yield $\left(1800 \mathrm{~kg} \mathrm{ha}^{-1}\right)$ followed by Spinosad 45 SC @ 75 g a.i. ha-1 ${ }^{-1}\left(1717 \mathrm{~kg} \mathrm{ha}^{-1}\right)$. Similarly, Sarnaik and Chiranjeevi (2017) also recorded maximum grain yield of chickpea $\left(2196 \mathrm{~kg} \mathrm{~h}^{-1}\right)$ with the application of Emamectin benzoate 5 WG @ 15.0 g a.i. ha-1.

\subsection{Phytotoxicity effect of Emamectin benzoate 5\% WG on chickpea crop}

On the basis of crop health and by visual observation, results clearly indicated that no phytotoxicity effects and symptoms were observed in the plots treated with Emamectin benzoate 5\%WG @ 5.6, 6.9, 8.1, 9.4 and 18.8 g a.i. ha ${ }^{-1}$ (Table 4). Similar findings were also reported by Nishantha et al. (2009) on chickpea. The present finding confirms the findings of Kambrekar et al. (2012), they also reported that the application of different doses of Emamectin benzoate 5\% SG had no adverse effects on chickpea crop.

\section{Conclusion}

Emamectin benzoate 5\% WG @ 9.4 and 8.1 g a.i. ha ${ }^{-1}$ were found to be the most effective dose for reducing the larval population of $\mathrm{H}$. armigera in chickpea which had given
Table 4: Effect of Emamectin benzoate 5\% WG on natural enemies of $H$. armigera infesting chickpea crop (Pooled data of 2009 and 2010)

\begin{tabular}{|c|c|c|c|c|}
\hline \multirow[t]{2}{*}{$\begin{array}{l}\text { SI. } \\
\text { No. }\end{array}$} & \multicolumn{2}{|c|}{ Dose } & \multicolumn{2}{|c|}{$\begin{array}{c}\text { Population of natural } \\
\text { enemies } / \mathrm{mrl}^{*}\end{array}$} \\
\hline & $\begin{array}{l}\text { g a.i } \\
\text { ha }^{-1}\end{array}$ & $\begin{array}{l}\text { Product } \\
\left(\mathrm{g}, \mathrm{ml} \mathrm{ha}^{-1}\right)\end{array}$ & $\begin{array}{l}\text { Adult lady bird } \\
\text { beetle }\end{array}$ & $\begin{array}{c}\text { Adult } \\
\text { chrysopa }\end{array}$ \\
\hline $\mathrm{T}_{1}$ & - & - & $0.52(1.01)$ & $\begin{array}{c}0.55 \\
(1.02)\end{array}$ \\
\hline $\mathrm{T}_{2}$ & 5.6 & $112 \mathrm{~g}$ & $0.51(1.00)$ & $\begin{array}{c}0.54 \\
(1.02)\end{array}$ \\
\hline $\mathrm{T}_{3}$ & 6.9 & $138 \mathrm{~g}$ & $0.51(1.00)$ & $\begin{array}{c}0.52 \\
(1.01)\end{array}$ \\
\hline $\mathrm{T}_{4}$ & 8.1 & $162 \mathrm{~g}$ & $0.49(0.99)$ & $\begin{array}{c}0.53 \\
(1.01)\end{array}$ \\
\hline$T_{5}$ & 9.4 & $188 \mathrm{~g}$ & $0.41(0.95)$ & $\begin{array}{c}0.46 \\
(0.98)\end{array}$ \\
\hline$T_{6}$ & 500 & $2500 \mathrm{ml}$ & $0.25(0.86)$ & $\begin{array}{c}0.35 \\
(0.92)\end{array}$ \\
\hline $\mathrm{T}_{7}$ & 500 & $1000 \mathrm{ml}$ & $0.34(0.92)$ & $\begin{array}{c}0.41 \\
(0.95)\end{array}$ \\
\hline SEm & & & 0.003 & 0.007 \\
\hline $\mathrm{CD}($ & .05) & & 0.009 & 0.021 \\
\hline
\end{tabular}

Figures in parenthesis are square root transformed values $(\mathrm{V}+0.5), \mathrm{mrl}^{-1^{*}}=$ meter row length

maximum seed yield. Whereas the higher dose of Emamectin benzoate 5\% WG 9.4 g a.i. ha-1 did not cause any phytotoxicity symptoms on chickpea crop and had no adverse effects on the activity of natural enemies.

\section{References}

Agricultural Statistics at a Glance, 2016. Government of India ministry of agriculture and farmers welfare department of agriculture, Cooperation and Farmers Welfare Directorate of Economics and Statistics 111.

Arora, R., Sharma, H.C., Dreissche, E.V., 2005. Biological activity of lectins from grains legumes and garlic against the legume pod borer, Helicoverpa armigera. Journal of ICRISAT Organization 1(1), 1-3.

Bharti, P., Singh, S.P.N., Kumar, N., 2015. Efficacy of some insecticides, bio-products and their phytotonic effect against gram pod borer (Helicoverpa armigera Hub.) in chickpea. Current Biotica 9, 247-255.

Chandrashekar, K., Gupta, O., Yelshetty, S., Sharma, O.P., Bhagat, S., Chattopadhyay, C., Sehgal, M., Kumari, A., Amaresan, N., Sushil, S.N., Sinha, A.K., Asre, R., Kapoor, K.S., Satyagopal, K., Jeyakumar, P., 2014. Integrated Pest Management for Chickpea. NCIPM, LBS Building, IARI Campus, New Delhi, 43. 
Kambrekar, D.N., Somanagouda, G., Basavarajappa, M.P., Halagalimath, S.P., 2012. Effect of different dosages of Emamectin benzoate 5 SG and Indoxacarb 14.5 SC on pod borer, Helicoverpa armigera infesting chickpea. Legume Research 35, 13-17.

Kumar, G.V.S., Sarada, O., 2015. Field efficacy and economics of some new insecticide molecules against lepidopteran caterpillars in chickpea. Current Biotica 9, 153-158.

Kumar, S.V.S., Prakash, J.C., Kumar, B.A., 2013. Identification of chickpea genotypes for resistance to pod borer and Fusarium Wilt. Bioinfolet- A Quarterly Journal of Life Sciences, 10 (2B), 745-749.

Kumar, M., Kumar, N., Malik, S., Kumar, A., Kumar, V., 2015. Molecular characterization of chickpea (Cicer arietinum L.) through RADP and ISSR markers. Progressive Agriculture 15(2), 277-284.

Mandal, S.K., Roy, S.P., 2012. Impact of environmental factor (s) on certain pulse crops of north-eastern Bihar (India) with reference to resource management. The Ecoscan 1(Special Issue), 35-40.

Mittal, V., Ujagir, R., 2005. Evaluation of naturalyte spinosad against pod borer complex in early pigeonpea. Indian Journal of Plant Protection 33, 211-215.

Nayer, K.K., Ananthkrishan, T.N., David, B.V., 1982. General and Applied Entomology, Tata Mc Graw Hill Publishing Company Ltd., New Delhi, 589.

Nishantha, K.M.D.W.P., Bhosale, B.B., Kadam, D.R., Patange, N.R., 2009. Comparison of new insecticide molecule, E2Y45 with microbial agents and other insecticides on parasitoids and predators and its phytotoxicity to pigeonpea. Journal of Plant Protection and Environment 6(2), 111-116.

Raghuraman, M., Birah, A., Singh, B., Gupta, G.P., 2008. Bioefficacy of a newer insecticide Emamectin benzoate $5 \%$ EC against cotton Boll worms. Indian Journal of Entomology 70, 264-268.

Rai, D., Ujagir, R., Singh, R.K., 2003. The larval parasitization by Campoletis chloridae Wchida (Hymenoptora: Ichneumonidae) of Helicoverpa armigera (Hubner) in pure chickpea crop at Pantnagar. Journal of Biocontrol 17, 81-83.

Sachan, J.N., 1992. Present status of Helicoverpa armigera in pulses and strategies for its management. In: Sachan, J.N. (ed.) "Helicoverpa Management: current status and future strategies", Proceedings of First National Workshop, held at Directorate of Pulse Research, Kanpur, India, 30-31, August 1990, 7-32.

Saharan, K., Khetarpaul, N., 1994. Protein quality traits of vegetable and field peas: Varietal differences. Plant Foods Human Nutrition 45, 11-22.

Sarnaik, S.V., Chiranjeevi, B., 2017. Bioefficacy of newer insecticides against gram pod borer, Helicoverpa armigera (Hubner) on chickpea.The Bioscan 12(1), 65-69.

Sharma, O.P., Bhosle, B.B., Kamble, K.R., Bhede, B.V., Seeras, N.R., 2011. Management of pigeonpea pod borers with special reference to pod fly (Melanagromyza obtusa). Indian Journal of Agricultural Sciences 81, 539-543. 